\title{
Evaluation of the Relationship between Healthy Lifestyle Behaviors and the Risk of Type 2 Diabetes in Healthcare Professionals
}

\author{
Emine KAPLAN SERİN ${ }^{1}$, Kevser IŞIK ${ }^{2} \oplus \bowtie$, Ahmet ÖZDEMİR ${ }^{3}$ (1) \\ ${ }^{1}$ Gaziantep University, Faculty of Health Sciences, Department of Internal Medicine Nursing, Gaziantep, Turkey \\ ${ }^{2}$ Kahramanmaraş Sütçü Imam University, Faculty of Health Sciences, Department of Public Health Nursing, Kahramanmaraş, Turkey \\ ${ }^{3}$ Kahramanmaraş Sütçü Imam University, Faculty of Health Sciences, Department of Surgical Nursing, Kahramanmaraş, Turkey \\ Cite this article as: Kaplan Serin E et al. Evaluation of the Relationship between Healthy Lifestyle Behaviors and the Risk of Type 2 Diabetes in Healthcare Professionals. \\ Turk J Diab Obes 2021;2: 118-123.
}

\begin{abstract}
Aim: The aim of this study was to investigate the relationship between healthy lifestyle behaviors and the risk of type 2 diabetes in healthcare professionals.

Material and Methods: The study was conducted with 164 volunteering physicians and nurses employed in a Health Practice and Research Hospital in southeastern Turkey. A descriptive questionnaire, the Finnish Diabetes Risk Score and the Healthy Lifestyle Behaviors Scale were used to collect the data.

Results: It was determined that the diabetes risk levels of the participants were low, while their healthy lifestyle behaviors were on a moderate level. A significant negative correlation was found between the participants' mean diabetes risk scores and their health lifestyle behavior scores $(\mathrm{p}<0.05)$. Accordingly, as the levels of the healthy lifestyle behaviors of the participants decreased, their risk of diabetes increased. It was found that other predictors such as the body mass index, high blood glucose and daily exercise had a cumulative effect of up to $65 \%$ on the risk of diabetes.

Conclusion: Even though the participants' mean age was young, and their mean BMI was in the normal category, their low rates of daily exercise suggested that their risk of type 2 diabetes may increase in the future.
\end{abstract}

Keywords: Diabetes risk, Healthy lifestyle, Physician, Nurse

\section{Sağlık Ekibinin Sağlıklı Yaşam Biçimi Davranışları ve Tip 2 Diyabet Riski İlişkisinin Değerlendirilmesi}

\section{ÖZ}

Amaç: Bu araştırma, sağlık profesyonellerinin sağlıklı yaşam biçimi davranışları ve tip 2 diyabet riski ilişkisinin değerlendirilmesi amaciyla yapildi.

Gereç ve Yöntemler: Bu araştırma Türkiye’nin güneydoğusunda yer alan bir Sağlık Uygulama ve Araştırma Hastanesinde çalışan ve gönüllü olan 164 hekim ve hemşirelerle yapıldı. Tanımlayıcı ve kesitsel tipte yapılan araştırmada veriler sosyo-demografik özellikler, Tip 2 Diyabet Risk Anketi ve Sağlıklı Yaşam Biçimi Davranışları Ölçeği kullanılarak toplanmıştır.

Bulgular: Araştırmaya katılanların diyabet risk anketinden aldıkları puan ortalamasının $6.45 \pm 4.08$ ile çok düşük risk, sağlıklı yaşam

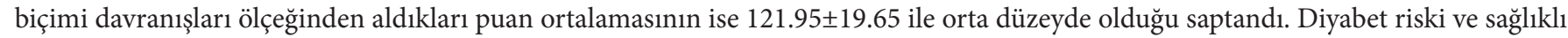
yaşam biçimi davranışları ölçeği puan ortalamaları arasında negatif yönde anlamlı bir ilişki belirlendi (p<0.05). Sağlıklı yaşam biçim davranış düzeyi azaldıkça, diyabet riski artmaktadır. Beden kütle indeksi, yüksek kan glikoz değeri, günlük egzersiz diğer yordayıcılardan olup kümülatif olarak \%65 diyabet riski üzerinde etkili olduğu saptandı ( $\mathrm{p}=.000)$.

Sonuç: Araştırmada katılımcıların yaş ortalamasının düşük BKİ skorunun normal olmasına rağmen günlük egzersize yönelenlerin düşük oranda olması bu riskin artmasına neden olacağını düşündürmektedir.

Anahtar Sözcükler: Diyabet riski, Sağlikl yaşam biçimi, Hekim, Hemşire

ORCID: Emine Kaplan Serin / 0000-0002-7327-9167, Kevser IŞIK / 0000-0001-9081-7660 , Ahmet Özdemir / 0000-0002-4492-8172 


\section{INTRODUCTION}

Today, diabetes is the most important and frequently seen public health problem owing to an increase in its risk factors. The increase in its prevalence is faster than expected (1-3). According to the estimates published by the International Diabetes Federation (IDF), at the end of 2017 , approximately 425 million people had diabetes, and this figure was expected to hit 630 million with an increase of $48 \%$ by $2045(3,4)$. The increase in the prevalence of type 2 diabetes reaches up to $80 \%$ in low- and middle-income countries (1-3). The Turkish Diabetes Epidemiology (TURDEP-2) study showed that the prevalence of diabetes in Turkey increased from $7.2 \%$ to $13.7 \%(3,5,6)$. Diabetes develops as a result of several factors including genetic, environmental and lifestyle-related changes $(3,7)$. Obesity, a sedentary lifestyle, nutrition, reduced sleep and depressive symptoms are defined as modifiable risk factors for type 2 diabetes (7-9)

IDF defines three main steps as a diabetes prevention strategy: identification of risk groups, measurement of risk and interventions to prevent the development of type 2 diabetes. IDF recommends the use of risk scales such as the Finnish Type 2 Diabetes Risk Score (FINDRISC) to identify the individuals at risk as the first step $(4,10)$.

Healthy lifestyle is defined as keeping in check the type of behaviors that may affect health and organizing daily activities with the best interests in terms of a healthy existence in mind $(11,12)$. Behavioral patterns, activities and habits are linked to the protection and improvement of a healthy existence. Where people are not accurately informed about their own health and do not acquire the skills to make good choices in terms of their health, they continue to keep unhealthy lifestyle behaviors because of their lack of understanding of what is good or bad for their health (13). Healthy lifestyle behaviors include taking responsibility for one's own health, self-realization (fulfilling the requirements of professional competence), health checks, stress management, nutrition and exercise $(10,14)$. Studies have demonstrated that it is possible to prevent obesity and type 2 diabetes with increased physical activity and changing detrimental eating habits $(2,14)$. In a study on risk factors and risk groups of type 2 diabetes, it was found that nurses were at a higher risk of type 2 diabetes in comparison to other healthcare professionals (15). Once again, this shows the importance of a healthy lifestyle and improving healthy behaviors for healthcare professionals, especially nurses providing healthcare services (10).

Given their professional responsibilities and the social role they undertake, healthcare professionals should be a role model for society at large with their lifestyle. After all, they have the ability to influence the people they serve in the form of providing them with health education $(1,10,12,14)$. Healthcare professionals have an important part to play in leading by example for practicing and improving sustainable healthy lifestyle behaviors in society as a whole (12). Studies have shown that healthcare professionals who do not display healthy lifestyle behaviors themselves have a hard time getting their patients to follow their advice and adhere to healthy practices $(11,14)$. In addition to this, studies have also revealed that healthcare professionals do not completely achieve healthy lifestyle behaviors on the desired level $(11,12,14)$. Consequently, healthcare professionals should first and foremost improve their knowledge and awareness on matters of health and then develop the necessary attitudes and behaviors. They need to be better equipped about healthy lifestyle changes to improve their own lifestyles $(16,17)$. The aim of this study was to evaluate the relationship between type 2 diabetes risk and healthy lifestyle behaviors in healthcare professionals.

\section{MATERIALS and METHODS}

\section{Design}

This study was designed as a descriptive and correlational study.

\section{Location}

The study was conducted between January 2019 and April 2019 with physicians and nurses employed in a Health Practice and Research Hospital in southeastern Turkey.

\section{Population and Sample}

The population of the study consisted of all physicians and nurses employed in the hospital where the study was conducted. Since it was aimed to reach the entire population within the given time, no sampling method was used. The sample comprised a total of 164 physicians and nurses who consented to participate in the study within the time interval specified above.

\section{Data Collection Tools and Process}

The data collection tools consisted of an introductory questionnaire with a total of 11 questions on the introductory characteristics of the participants (e.g., age, gender, education level), the Finnish Diabetes Risk Score and the Healthy Lifestyle Behaviors Scale.

\section{Finnish Diabetes Risk Score (FINDRISC)}

FINDRISC was developed in Finland in 2003 as a result of a cohort study (18). The Turkish translation of the scoring system was undertaken by the Turkish Society of 
Endocrinology and Metabolism. FINDRISC is used to determine the individual's risk of developing diabetes in the next 10 years. It consists of 8 questions in total. The maximum possible score is 26 . A score of 15 or above indicates increased risk (3). Accordingly, FINDRISC values of lower than 7 are considered to indicate a very low diabetes risk, scores of 7-11 indicate a low risk, scores of 1214 indicate a moderate risk, scores of 15-20 indicate a high risk, and scores of 21 or higher indicate a very high risk (19).

\section{Healthy Lifestyle Behaviors Scale}

The scale was developed by Walker et al. in 1987 and revised in 1996 (20). Its Turkish validity and reliability study was performed by Bahar et al. in 2008. The scale consists of 52 items and 6 dimensions. The minimum and maximum possible total scores for the scale are 52 and 208. The Cronbach's alpha coefficient of the scale was reported as 0.92 (21). In our study, the Cronbach's alpha value of the scale was calculated as 0.93 .

\section{Statistical Analysis}

The collected data were analyzed with the SPSS 22.0 software package. The descriptive analysis of the data was based on percentages, means and standard deviations. Correlation analysis was performed between the variables of diabetes risk and healthy lifestyle behaviors. Stepwise regression analyses were performed. In the first application, the type 2 diabetes scores of the participants were evaluated based on some independent variables. In the second application, the healthy lifestyle behavior scores of the participants were been assessed based on some independent variables. Prior to the regression analysis, multicollinearity among the independent variables was checked, and there were no issues of multicollinearity among the variables. The results were accepted as statistically significant in a confidence interval of $95 \%$ and on a significance level of $\mathrm{p}<0.05$.

\section{RESULTS}

It was found that $79.9 \%$ of the participants were female, $38.4 \%$ had undergraduate degrees, $72.6 \%$ were nurses, $87.8 \%$ had no chronic illness, $45.1 \%$ perceived their own health as good, $79.9 \%$ did not smoke, $75.6 \%$ did not exercise daily, 54.9\% consumed fruits and vegetables daily, 90.9\% did not have high blood glucose values, the mean age of the participants was $29.16 \pm 6.39$ years, and their mean body mass index was $24.42 \pm 3.85$ (Table 1 ).

It was determined that the mean score of the participants in FINDRISC was $6.45 \pm 4.08$, which indicated a very low risk. Their mean score in the Healthy Lifestyle Behaviors Scale II was found as $121.95 \pm 19.65$, which indicated a moderate
Table 1: Sociodemographic characteristics of participants.

\begin{tabular}{|c|c|c|}
\hline Characteristic & Number & $\%$ \\
\hline \multicolumn{3}{|l|}{ Gender } \\
\hline Female & 131 & 79.9 \\
\hline Male & 33 & 20.1 \\
\hline \multicolumn{3}{|l|}{ Level of education } \\
\hline High school & 36 & 22.0 \\
\hline Two-year degree & 23 & 14.0 \\
\hline Undergraduate & 63 & 38.4 \\
\hline Postgraduate & 42 & 25.6 \\
\hline \multicolumn{3}{|l|}{ Occupation } \\
\hline Nurse & 119 & 72.6 \\
\hline Physician & 45 & 27.4 \\
\hline \multicolumn{3}{|l|}{ Chronic illness } \\
\hline Yes & 20 & 12.2 \\
\hline No & 144 & 87.8 \\
\hline \multicolumn{3}{|c|}{ Self-perceived health } \\
\hline Excellent & 61 & 37.2 \\
\hline Good & 74 & 45.1 \\
\hline Moderate & 25 & 15.2 \\
\hline Poor & 4 & 2.5 \\
\hline \multicolumn{3}{|l|}{ Smoking } \\
\hline Yes & 33 & 20.1 \\
\hline No & 131 & 79.9 \\
\hline \multicolumn{3}{|l|}{ Daily exercise } \\
\hline Yes & 40 & 24.4 \\
\hline No & 124 & 75.6 \\
\hline \multicolumn{3}{|c|}{ Daily fruit and vegetable consumption } \\
\hline Yes & 90 & 54.9 \\
\hline No & 74 & 45.1 \\
\hline \multicolumn{3}{|l|}{ High glucose value } \\
\hline Yes & 15 & 9.1 \\
\hline No & 149 & 90.9 \\
\hline Age (Year \pm SD) & \multicolumn{2}{|c|}{$29.16 \pm 6.39$} \\
\hline BMI $($ Mean \pm SD $)$ & \multicolumn{2}{|c|}{$24.42 \pm 3.85$} \\
\hline
\end{tabular}

level of healthy lifestyle behaviors among the participants. A significant negative correlation was found between the mean scores of the participants in FINDRISC and the Healthy Lifestyle Behaviors Scale II ( $\mathrm{p}<0.05)$ (Table 2). Accordingly, as the levels of the participants' healthy lifestyle behaviors increased, their risk of diabetes decreased. 
In the analyses performed with the stepwise linear regression method, the body mass index (BMI) turned out as the first predictor of diabetes risk, accounting for $40 \%$ of the factors affecting the latter. A high blood glucose value and daily exercise were the other predictors with a cumulative effect of $65 \%$ in diabetes risk $(\mathrm{p}=.000)$ (Table 3$)$.

In the analyses performed with the stepwise linear regression method, self-perceived health appeared as the first predictor of healthy lifestyle behaviors, accounting for $31 \%$ of the factors affecting it. Self-perceived health, chronic illness, daily exercise, and education level had a cumulative effect of $41 \%$ in healthy lifestyle behaviors ( $\mathrm{p}=.000)$ (Table 4).

Table 2: The relation between diabetes risk and healthy lifestyle behaviors.

\begin{tabular}{|c|c|c|}
\hline Scales & & \\
\hline & Mean \pm SD & \multirow{3}{*}{$\begin{array}{c}\mathrm{r}=-.177^{\star} \\
\mathrm{p}=.023\end{array}$} \\
\hline Diabetes risk & $6.45(4.08)$ & \\
\hline Healthy lifestyle & 121.95 (19.65) & \\
\hline
\end{tabular}

\section{DISCUSSION}

Diabetes is a chronic metabolic disease requiring continuous medical care $(3,7,22)$. Professionals in the health sector may often neglect their own care as they work hard to provide care for their patients (23). However, healthy lifestyle behaviors are of crucial importance in healthcare professionals as they are a group that needs to lead by example (7).

It was found that, among the 164 healthcare professionals who participated in this study, $79 \%$ were female, $38 \%$ had an undergraduate degree, and $12 \%$ had a chronic disease. Furthermore, 45\% perceived their own health as good, $24 \%$ exercised daily, and 9\% had high blood glucose levels. While healthcare professionals meet their patients' healthcare needs in their professional life, they often cannot find opportunities for exercise, which is a healthy lifestyle behavior. This situation makes us think that they are a risk group for diabetes.

It was ascertained in this study that healthy lifestyle behaviors reduced the risk of diabetes in the participating healthcare professionals. The findings of this study were

Table 3: According to regression analysis predictors of diabetes risk survey.

\begin{tabular}{|c|c|c|c|c|c|c|c|c|}
\hline & \multicolumn{2}{|c|}{ Unstandardized Coefficients } & \multicolumn{5}{|c|}{ Standardized Coefficients } & \multirow[t]{2}{*}{ R square } \\
\hline & $\beta$ & Std Error & $\beta$ & $\mathbf{t}$ & Sig. & $\mathbf{F}$ & Sig. & \\
\hline (Constant) & 1.447 & 2.698 & & 0.536 & 0.593 & \multirow{4}{*}{54.309} & \multirow{4}{*}{$<0.001^{\mathrm{b}}$} & \multirow{4}{*}{0.652} \\
\hline BMI & 0.600 & 0.071 & 0.548 & 8.419 & $<0.001$ & & & \\
\hline $\begin{array}{l}\text { High blood } \\
\text { glucose value }\end{array}$ & -6.737 & 0.929 & -0.461 & -7.249 & $<0.001$ & & & \\
\hline Daily exercise & 1.953 & 0.642 & 0.197 & 3.040 & $<0.001$ & & & \\
\hline
\end{tabular}

Dependent Variable: Diabetes risk

'Predictors: (Constant), BMI, High blood glucose value, Daily exercise

Table 4: According to regression analysis predictors of Healthy Lifestyle Behaviors.

\begin{tabular}{|c|c|c|c|c|c|c|c|c|}
\hline & \multicolumn{2}{|c|}{ Unstandardized Coefficients } & \multicolumn{5}{|c|}{ Standardized Coefficients } & \multirow[t]{2}{*}{ R square } \\
\hline & $\beta$ & Std Error & $\beta$ & $\mathbf{t}$ & Sig. & F & Sig. & \\
\hline (Constant) & 140.659 & 12.708 & & 11.068 & $<0.001$ & \multirow{5}{*}{15.290} & \multirow{5}{*}{$<0.001^{\mathrm{b}}$} & \multirow{5}{*}{0.416} \\
\hline $\begin{array}{l}\text { Self-perceived } \\
\text { health }\end{array}$ & -10.545 & 1.888 & -0.499 & -5.586 & $<0.001$ & & & \\
\hline Chronic illness & 10.552 & 4.852 & 0.182 & 2.175 & 0.032 & & & \\
\hline Daily exercise & -10.402 & 4.190 & -.219 & -2.482 & 0.015 & & & \\
\hline Education level & 3.466 & 1.652 & 0.180 & 2.098 & 0.039 & & & \\
\hline
\end{tabular}

Dependent Variable: Healthy lifestyle total

bPredictors: (Constant), Self-perceived health, Chronic illness, Daily exercise, Education 
in line with other studies in the literature $(3,7,22,23)$. In this study, BMI appeared as the most important factor in the diabetes risk of the participants $(\mathrm{p}<0.001)$. Arpac1 et al. evaluated the diabetes risk of hospital employees and found that BMI significantly increased the risk of diabetes (22). Another study reported that an increase in BMI significantly increased the risk of diabetes (2). The findings of our study tended to support those reported in previous studies. The parameter with the greatest effect on healthy lifestyle behaviors was found to be self-perceived health, while chronic disease, daily exercise and education level also had significant effects $(\mathrm{p}<0.001)$. As a chronic disease that may cause lifelong health complications, type 2 diabetes is correlated with the individual's positive assessment of their health and their development of healthy lifestyle behaviors (24). Likewise, İlbars and Özkan found that healthy lifestyle behaviors are most influenced by the individual's approach to matters of belief (25). On an individual level, good health is defined as physical, mental and psychosocial wellbeing (26). Positive beliefs and attitudes are considered to constitute guidance for the individual for a better health perception, thus developing healthy lifestyle behaviors.

It is important to protect healthcare professionals against diabetes, because as the segment of the society providing healthcare, they should lead by example. In our study, the mean age of the participants was young, and their mean BMI was in the normal category. Nonetheless, their low rate of daily exercise suggested a risk with the potential to increase. Therefore, it is recommended to encourage healthy lifestyle behaviors, including physical exercise, healthy nutrition and sufficient daily rest during the intensive work schedule of healthcare professionals to reduce their risk of diabetes.

Since the study was limited to healthcare professionals working at the aforementioned university hospital, it cannot be generalized to all healthcare professionals. Nevertheless, the results of the study may be used for comparison to the findings of different studies. Due to the heavy workload of healthcare professionals who had the potential to participate in the study, it was difficult to reach more participants in the data collection process. This was another limitation of the study.

\section{Acknowledgement}

None.

\section{Authorship Contributions}

Concept: Emine Kaplan Serin, Design: Emine Kaplan Serin, Data Collection or Processing: Ahmet Özdemir, Kevser Işık, Analysis or Interpretation: Kevser Issık, Literature Search: Emine Kaplan Serin, Kevser Işık, Ahmet Özdemir, Writing: Emine Kaplan Serin, Kevser Işık, Ahmet Özdemir.

\section{Conflicts of Interest}

The authors declare that they have no competing interest.

Financial Disclosure

The authors received no financial support for this study.

\section{Ethical Approval}

The study was conducted with the written approval of the NonInvasive Studies Ethics Board of a state university (2018/1884). Furthermore, written permission was obtained from the Chief Physician of the Health Practice and Research Hospital in southeastern Turkey where the study was conducted. The participants were informed about the aim and purpose of the study, and their verbal consent was obtained.

\section{Peer Review Process}

Extremely peer-reviewed.

\section{REFERENCES}

1. Koçak HS, Öncel S, Zincir H, Seviğ EÜ. Determining primary school teachers' type 2 diabetes risk and healthy lifestyle behaviors. Turk J Public Health. 2017;15(2):70-83.

2. Doğan B, Yörük N, Öner C, Yavuz G, Oğuz A. Evaluation of diabetes risk and eating habits of university students and personnel. Turkish Journal of Family Practice. 2017; 21: 50-55.

3. Kulak E, Berber B, Temel H, Kutluay SN, Yildirim M, Dedeoğlu FN, Çifçili S, Save D. Determination of type 2 diabetes risk levels in individuals applying to family medicine. Turkish Journal of Family Practice. 2019;23:21-30.

4. International Diabetes Federation, Diabetes Atlas, 8 th edition, 2017. http://www.diabetesatlas.org. Erişim Tarihi: 01.03.2020

5. Gezer C. The assesment of relation between waist/height ratio and type 2 diabetes risk among nursing students. Journal of Food and Health Science. 2017;3:141-149.

6. Satman I, Yilmaz T, Sengül A, Salman S, Salman F, Uygur S, Bastar I, Tütüncü Y, Sargin M, Dinççag N, Karsidag K, Kalaça S, Ozcan C, King H. Population-based study of diabetes and risk characteristics in Turkey: Results of the turkish diabetes epidemiology study (TURDEP). Diabetes Care. 2002;25:15511556.

7. Kyrou I, Tsigos C, Mavrogianni C, Cardon G, Van Stappen V, Latomme J, Manios Y. Sociodemographic and lifestylerelated risk factors for identifying vulnerable groups for type 2 diabetes: A narrative review with emphasis on data from Europe. BMC Endocr Disord. 2020;20:1-13.

8. Amuta AO, Jacobs W, Barry AE. An examination of family, healthcare professionals, and peer advice on physical activity behaviors among adolescents at high risk for type 2 diabetes. Health Commun. 2017; 32: 857-863

9. Saylor JL, Calamaro CJ, Hardie T, Ness M, Selekman J. Are college students told by health care providers about their risk factors for developing diabetes? J Am Assoc Nurse Pract. 2018;30(7):398-405. 
10. de Lima CLJ, Costa MML, dos Santos Oliveira J, Ferreira TMC, Ferreira JDL, Do Nascimento JA. Risk screening for Diabetes Mellitus development in users of basic health care. Enfermería Global. 2018;17:124-136.

11. Özcan S, Bozhüyük A. Healthy life behaviors of the health science students of Cukurova University. Cukurova Med J. 2016; 41:664-674.

12. Altay B, Çavuşoğlu F, Güneștaş İ. Healthy life style behaviours and influencing factors of nurses who work at the university hospital. Dokuz Eylül Üniversitesi Hemşirelik Fakültesi Elektronik Dergisi. 2015;8:12-18.

13. Çakır M, Piyal B, Aycan S. Healthy lifestyle behaviors and quality of life in physicians: a faculty of medicine based crosssectional study. Ankara Med J. 2015;15:209-219.

14. Akçakanat T, Toraman A, Çarıkçı IH. The evaluation of healthy lifestyle behaviors for the lecturers of the faculty of medicine. Mehmet Akif Ersoy University Journal of Social Sciences Institute. 2015; 7: 84-97.

15. Almeida VC, Zanetti ML, Almeida PC, Damasceno MM. Occupation and risk factors for type 2 diabetes: A study with health workers. Revista Latino-Americana de Enfermagem. 2011; 19: 476-484.

16. Tedik S. Healthy life and role of nursing in the control of body weight. Turk J Diab Obes. 2017;1:54-62.

17. Cürcani M, Tan M, Özdelikara A. Healthy life style behaviours of the nurses and the determination of affecting factors. TAF Prev Med Bull. 2010;9:487-492.

18. Lindström J, Tuomilehto J. The diabetes risk score: A practical tool to predict type 2 diabetes risk. Diabetes Care. 2003;26(3):725-731.
19. Vandersmissen GJM, Godderis L. Evaluation of the Finnish Diabetes Risk Score (FINDRISC) for diabetes screening in occupational health care.Int J Occup Med Environ Health. 2015;28(3):587-591.

20. Walker SN, Sechrist KR, Pender NJ. The health-promoting lifestyle profile: Development and psychometric characteristics. Nurs Res. 1987;36(2):76-81.

21. Bahar Z, Beşer A, Gördes N, Ersin F, Kissal, A. Healthy life style behavior scale ii: A reliability and validity study. C.Ü. Hemşirelik Yüksekokulu Dergisi. 2008;12: 1-13.

22. Arpacı İ, Olgun N, Arpacı İE. Assessment of diabetes risk in hospital employees. Diyabet, Obezite ve Hipertansiyonda Hemşirelik Forumu Dergisi. 2017; 11:7-11.

23. Alaofè H, Asaolu I, Ehiri J, Moretz H, Asuzu C, Balogun M, Abosede O, Ehiri J. Community health workers in diabetes prevention and management in developing countries. Ann Glob Health. 2017;83(3-4):661-675.

24. Kaneko K, Yatsuya H, Li Y, Uemura M, Chiang C, Hirakawa Y, Ota A, Tamakoshi K, Aoyama A. Risk and population attributable fraction of metabolic syndrome and impaired fasting glucose for the incidence of type 2 diabetes mellitus among middle-aged Japanese individuals: Aichi Worker's Cohort Study. J Diabetes Investig. 2020;11(5):1163-1169.

25. İlbars H, Ozkan S. Healthy life-style patterns of pharmacists in Turkey. EMU JPharm Sci. 2019; 2(2): 84-94.

26. World Health Organization. Mental health: strengthening our response https://www.who.int/. April 2, 2020. 